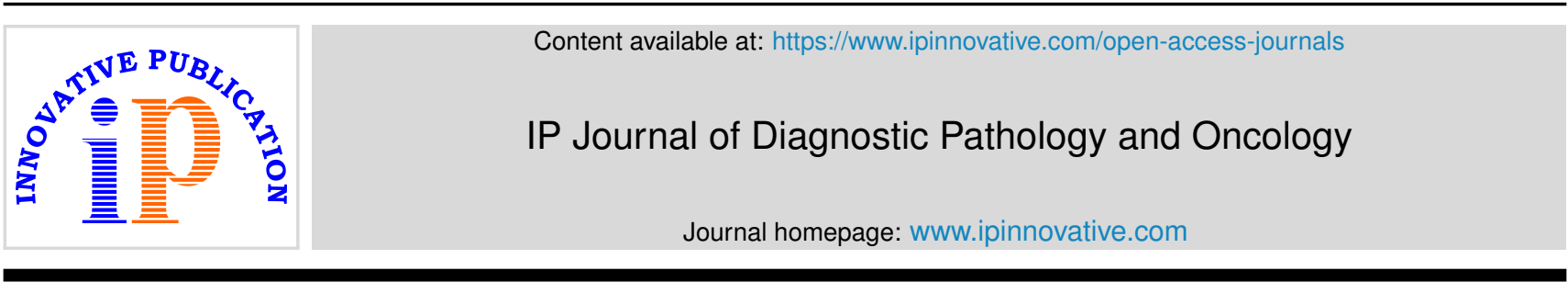

Original Research Article

\title{
Pattern of expression of Delta-like ligand 4 (DLL-4) in patients with pancreatic ductal and ampullary adenocarcinomas and its clinicopathological prognostic implications
}

\author{
Ikbal A Elkholy ${ }^{1}$, Asmaa M I Gado', Mie A Mohammad', Dalia H M Zayed², \\ Hend M H R Elkalla ${ }^{2}$, Ahmed M A Elhilali ${ }^{3}$, Sherine Refat ${ }^{1, *}$ \\ ${ }^{1}$ Dept. of Pathology, Faculty of medicine, Mansoura University, Egypt \\ ${ }^{2}$ Dept. of of Clinical Oncology and Nuclear Medicine, Faculty of Medicine, Mansoura University, Egypt \\ ${ }^{3}$ Dept. of General Surgery, Gastroenterology Center, Faculty of Medicine, Mansoura university, Egypt
}

\section{A R T I C L E I N F O}

\section{Article history:}

Received 17-07-2020

Accepted 23-07-2020

Available online 03-09-2020

\section{Keywords:}

DLL4; PDAC

Ampullary

adenocarcinoma

pancreatic

\begin{abstract}
A B S T R A C T
Background: There is an increasing interest for Notch signalling pathway and particularly Delta-like ligand 4 (DLL4), a Notch ligand as potential therapeutic target to improve outcome for patients with pancreatic ductal adenocarcinoma (PDAC).

Aim: characterize the expression of DLL4 in PDAC and ampullary adenocarcinoma (AA), evaluate their correlation with clinicopathologic features and patients' survival.

Materials and Methods: In a retrospective study, using immunohistochemistry, we assessed the expression of DLL4 in 62 cases composed of 39 cases of PDAC and 23 cases of AA undergone Whipple and received adjuvant chemotherapy and radiotherapy. We assessed the expression level of DLL4 both in tumor cells and stromal vascular endothelial cells. The relationships of DLL4 expression with clinico-pathologic parameters and clinical outcome were evaluated.

Results: There was no statistically significant relation between clinico-pathological parameters and DLL4 score expression in tumor cells of PDAC cases. However, there was statistically significant relation between DLL4 score expression in tumor cells of AA cases and tumor stage $(\mathrm{p}=0.041)$. Also, there was no statistical significance regarding DLL4 expression in stromal cells in PDAC and AA cases and clinico-pathological parameters. Regarding survival functions for pancreatic \& ampullary tumor cases; the median overall survival (OS) was 10 and 22 months for pancreatic (95\% CI: 1-45) and ampullary tumors (95\% CI: 169) respectively. OS for pancreatic and ampullary tumors was higher in cases with low DLL4 expression versus cases with high expressions with no statistically significance ( $\mathrm{P}=0.48 \& 0.09$ respectively). The median Progression free survival (PFS) was 7 and 17.5 months for pancreatic (95\% CI: 0-43) and ampullary tumors (95\% CI: 0-96) respectively. PFS was higher in cases with low DLL4 expression rather than cases with high expressions with no statistically significant differences $(\mathrm{P}=0.52$ and 0.19 respectively).

Conclusions: High DLL4 expression in cancer cells was associated with worse OS and DFS than low DLL4 expression.
\end{abstract}

(C) 2020 Published by Innovative Publication. This is an open access article under the CC BY-NC license (https://creativecommons.org/licenses/by-nc/4.0/)

\section{Introduction}

Pancreatic cancer is currently the $3^{\text {rd }}$ cause of cancer related deaths in USA. ${ }^{1}$ It is considered one of the most fatal cancers with a five-year survival rate

\footnotetext{
* Corresponding author.

E-mail address: sherine1982@yahoo.com (S. Refat).
}

of $8 \% .^{2}$ Pancreatic ductal adenocarcinoma (PDAC) is the most common malignant neoplasm of pancreas. It represents about $85 \%-90 \%$ of all pancreatic malignancies. ${ }^{3}$ Ampullary adenocarcinoma (AA) represents $0.5 \%$ of all gastrointestinal malignancies. In USA, this neoplasm grades as $85^{\text {th }}$ among males and 101st among females. Ampullary adenocarcinoma is cancer which anatomically centered at 
the ampulla of vater. They have a better prognosis when compared to similarly staged PDACs. ${ }^{4}$ They also have a better prognosis than duodenal and pancreaticobiliary neoplasms secondarily involving the ampulla. ${ }^{5}$

The pancreatic cancer incidence has increased over the last few years. To date, complete surgical resection of pancreatic cancer is the only treatment option, however the 5 -year survival of operated cases is only $20 \%$. Recurrence, either local or distant, is considered the main cause of death after surgical resection. The identification of specific factors that control an early postoperative failure in pancreatic cancer can lead to targeted adjuvant therapy and thus improve prognosis. ${ }^{6}$

An evolutionarily conserved intercellular signaling pathway affecting many differentiation processes and cell fate determination during embryonic and postnatal development is known as notch signaling pathway. This notch signaling has been shown to play an important role in the development of tumor vasculature and angiogenesis. ${ }^{7}$ An increasing interest in oncology research was focused on molecular markers of angiogenesis in order to select patients with a better prognosis, who are therefore in need of more targeted specific treatments. ${ }^{8}$

In human, classic notch signaling is composed of four notch receptors (Notch 1, 2, 3 and 4) and their ligands (deltalike 1, 3, 4 and jagged 1and 2). Some studies have focused on one of the notch ligands, delta-like ligand 4 (DLL4), which is induced by VEGF and acts downstream of VEGF as a "brake" on VEGF-induced vessel growth, forming an autoregulatory negative feedback loop inactivating VEGF. ${ }^{9}$

Since DLL4 plays a crucial role in angiogenesis of the tumor, its expression may be associated with poor prognosis in several human cancers including lung cancer, breast cancer, bladder cancer, ${ }^{10}$ clear cell renal cell carcinoma ${ }^{11}$ and is associated with poor clinical outcomes in gastric cancer. $^{12}$

DLL4 is expressed mainly in stromal endothelial cells lining the tumor vasculature and in the cytoplasm of tumor cells in the majority of tumors. ${ }^{13}$ DLL4 is also overexpressed in a large proportion of patients with PDAC. In addition, high DLL4 expression was correlated with poor clinical outcome and overall survival in patients with PDAC. 6

Furthermore, high expression of DLL4 was significantly correlated with TNM stage, histological grade and node stage of PDAC. ${ }^{13}$ Also, in PDAC, blockage of DLL4 receptors was associated with decrease of tumor volume, vascular density and inhibition of neovascularization. Overexpression of DLL4 induced chemo-resistance in PDAC by promoting epithelial-mesenchymal transition. ${ }^{14}$ Therefore, targeted inhibition of DLL4/Notch signaling is a new idea as a therapy for PDAC. ${ }^{13}$

Interestingly, DLL4 expression in other cancers is not always associated with a poor prognosis. For example,
DLL4 positivity was a good prognostic marker in lung adenocarcinoma. Organ specificity in the evaluation of DLL4 expression of various tumors should be considered. ${ }^{12}$

In addition, targeting DLL4 pathway may be a potential therapeutic option. By developing tumor recurrence models, Yen et al. demonstrated that the combination of anti-hDLL4 and anti-mDLL4 was effective in a broad spectrum of pancreatic tumor xenografts and added antitumor activity if combined with the standard gemcitabine chemotherapy. ${ }^{15}$

DLL4 expression in Ampullary adenocarcinoma is not well-studied. There are few substantial data reporting significant prognostic markers for AA. ${ }^{16}$

For these reasons, we attempted to study DLL4 expression in both tumor and stromal endothelial cells in all collected cases (PDAC and AA) and its correlation with clinico-pathological data and if there is a correlation between its expression and survival functions of the patients as regards progression free survival (PFS) and overall survival (OS).

\subsection{Patients \& Methods}

This retrospective study was performed on 62 cases (39 PDAC cases and 23 AA cases). The specimens were collected from surgical pathology laboratory at Gastroenterology Center, Mansoura University, Egypt through the period from $1^{\text {st }}$ of December 2014 to $31^{\text {st }}$ of December 2016 inclusive. Cases of PDAC and AA were resectable; all were operated by radical Whipple operation and were staged according to WHO classification 2018. We excluded non operable stage T4 \& M1 cases from our study. Demographic data were collected from the patients' clinical sheets. The patients received their adjuvant treatment Gemcitabine containing chemotherapy for 6 months and postoperative radiotherapy when indicated according to National Comprehensive Cancer Network (NCCN) guidelines. Regarding radiotherapy, it was taken when indicated; the patients were set-up and simulated for 3D conformal radiotherapy, and were generally placed supine in a reproducible, immobilized position. CT-based treatment planning was required for all patients.

\subsubsection{Target delineation}

1. The growth target volume (GTV) included the positive margin area defined according to the operation, radiological and pathological reports.

2. The clinical treatment volume (CTV) included the para-aortic nodes, pancreatico-jejunostomy, portal vein segment, superior mesenteric artery, celiac artery and the postoperative bed (Postop).

3. The planning target volume (PTV) was defined by adding $0.5 \mathrm{~cm}$ around CTV.

4. The boost for planning target volume (PTV2) was detected by adding $0.5 \mathrm{~cm}$ around GTV. 


\subsubsection{Dose and fractions}

1. PTV: $45 \mathrm{OO} \mathrm{CGY} / 25$ fractions.

2. PTV2: 5400CGY/30 fractions.

3. Organs at risk were delineated on CT cuts and they included stomach, bilateral kidneys, spinal cord, liver and bowel bag.

\subsubsection{Optimization of $3 D C R T$ plan}

1. A cumulative dose volume histogram (DVH).

2. PTV was covered by $95 \%$ of isodose curves.

3. Inhomogeneity ranged from $95 \%$ to $105 \%$ as possible.

4. Doses to organs at risk were limited to their tolerances

- Stomach: mean dose less than 30 Gy, D.max less than 54 Gy.

- Bilateral kidneys: $2 / 3$ of one kidney received $<30 \mathrm{~Gy}$, or $\mathrm{V} 15<30 \%$.

- Spinal cord: D.max received $<45$ Gy.

- Liver: mean dose of less than $25 \mathrm{~Gy}$.

- Bowel bag: D.max <54 Gy, D15\% <45 Gy.

\subsection{Machine}

3D CRT was delivered by high energy linear accelerator (Elekta, Precise Treatment System TM), Version 5, with 6 or $15 \mathrm{MEV}$ photon energy.

The patients were followed up at the clinical oncology and nuclear medicine department at Mansoura university hospital. Their clinical data were collected from electronic records and survival data were calculated as regard PFS and OS.

- Overall survival (OS): was calculated in months representing the time elapsing between the date of diagnosis of the disease and the date of death or losing the follow up.

- Progression free survival (PFS): was calculated in months representing the time elapsing between the end of the initial treatment till the disease progression either at surgical bed or at distant site.

Haematoxylin and eosin slides were reviewed, and we confirmed the previous diagnoses. Also, we assessed CAP protocol histopathological parameters such as size, site of tumor, histological grade, histological variant, pancreatic neck safety margin, lymphovascular and perineural invasion, precancerous lesions, regional lymph node affection, and TNM staging according to the latest staging system 2018. Immunohistochemical (IHC) staining of all of the studied cases was done. IHC staining was done on $4 \mu \mathrm{m}$ tissue thickness, obtained from paraffin embedded (FFPE) tissue sections. Paraffin was removed, and then tissue sections were incubated in xylene and rehydrated in a series of decreased concentration of ethanol. This was followed by Heat Induced Epitope Retrieval (HIER) using microwave and ethylene diamine tetra acetic acid (EDTA) buffer (PH 9). ${ }^{17}$

Upon completion, tissue sections were rinsed with 5 changes of distilled water and phosphate-buffered saline (PBS) and adequately immersed in $3 \%$ peroxidase-blocking solution of DAKO to inhibit endogenous peroxidase activity. Then, tissue sections were incubated with antibodies against DLL-4 (mouse polyclonal antibody, ab7280, Abcam, UK) for 60 minutes. ${ }^{18}$

DLL-4 antibody was received in a concentrated form and then was diluted in PBS with a dilution of 1:250. DAKO kit (Dako Detection System, Peroxidase/DAB+, Rabbit/Mouse, Produktionsvej 42, DK-2600, Glostrup, Denmark) was used. ${ }^{18}$

The antigen-antibody reaction was detected by diaminobenzidine tetrachloride in chromogen solution, and then tissue sections were counterstained with haematoxylin \& mounted. Between these steps, the samples were washed with phosphate buffered saline. ${ }^{17}$

\subsection{Immunohistochemical analysis and scoring}

DLL4 expression was detected in the cytoplasm, cell membrane of tumor cells and stromal endothelial cells as a brown staining. ${ }^{19}$ DLL4 expression was detected in normal kidney tubules as a positive control. ${ }^{11}$ As regards stromal tumor cells, DLL4 positive staining was considered if more than $10 \%$ of dominant staining intensity in stromal cells was detected. ${ }^{12}$

As regards DLL4 expression in tumor ductal cells, it was measured according to both percentage of staining tumor cells and intensity (no, low and high) of staining: a score of 0 was known by staining in $<5 \%$ of tumor cells, a score of 2 was known by high staining intensity in $>50 \%$ of tumor cells and a score of 1 was given to rest of cases. Then, expression was divided into 2 groups: low expression group (score 0-1) and high expression group (score 2). ${ }^{18}$

\subsection{Statistical analysis}

Data were analyzed using Statistical Package for Social Science software computer program version 23 (SPSS, Inc., Chicago, IL, USA). Quantitative parametric data were expressed as median, mean \pm standard deviation, while qualitative data were presented in a frequency (Number $\&$ percent). Student's t-test was used for comparing quantitative parametric data. Chi-square " $\chi 2$ ", Fischer's exact tests or Monte-Carlo, as indicated, were used to compare the qualitative data. Kaplan-Meier method was used for survival analysis. $\mathrm{P}$ value less than 0.05 was considered statistically significant. 


\section{Results}

\subsection{Patients' characteristics}

Sixty-two patients, who had undergone Whipple operation, were included in our study. Demographic, clinical and histopathological data are shown in Table 1. Age of PDAC cases ranged from 40 to 75 years, while age of AA cases ranged from 30 to 80 years. Regarding gender distribution, in PDAC cases male to female ratio was of 3.3:1 while in AA, it was 2.3:1.

\subsection{Immunohistochemical expression of DLL4 and its correlation with clinicopathological characteristics}

DLL4 expression was identified in the cytoplasm and cellular membrane of cancer cells and in stromal endothelial cells (Figure 1a-f).

As shown in (Table 2), there was no statistically significant relation between clinicopathological parameters and DLL4 score expression in tumor cells of PDAC cases. However, there was a statistically significant relation between DLL4 score expression in tumor cells of AA cases and tumor stage $(\mathrm{p}=0.041)$. (Table 3 ) showed that there was no statistically significant relation regarding DLL4 score expression in stromal cells in both PDAC and AA cases and clinicopathological parameters. Pancreatic tissue was negative for DLL4 and was not submitted for statistical analysis (Figure 1g).

Regarding survival functions for both pancreatic and ampullary tumor cases; the median OS was 10 and 22 months for pancreatic (95\% CI: 1-45) and ampullary tumors (95\% CI: 1-69), respectively. OS for pancreatic and ampullary tumors was higher in cases with low DLL4 expression than in cases with high expressions with no statistically significant difference $(\mathrm{P}=0.48$ and 0.09 respectively) (Figures 2 and 3 ).

The median PFS was 7 and 17.5 months for pancreatic (95\% CI: 0-43) and ampullary tumors (95\% CI: 0-96), respectively. PFS was higher in cases with low DLL4 expression than in cases with high expressions with no statistically significant difference $(\mathrm{P}=0.52$ and 0.19 respectively) (Figures 4 and 5 ).

Univariate analysis was done for both pancreatic and ampullary cases in correlation to patient's and tumor's characteristics for both OS and PFS and showed no significant difference except for age in AA cases as regard OS ( $\mathrm{P}=0.02)$ (Tables 4 and 5). Multivariate analysis was done and revealed no statistically significant difference between any of the patients and tumor characteristics and OS and PFS.

\section{Discussion}

This retrospective study was performed on 62 cases including 39 PDAC cases $(62.9 \%)$ and 23 AA cases

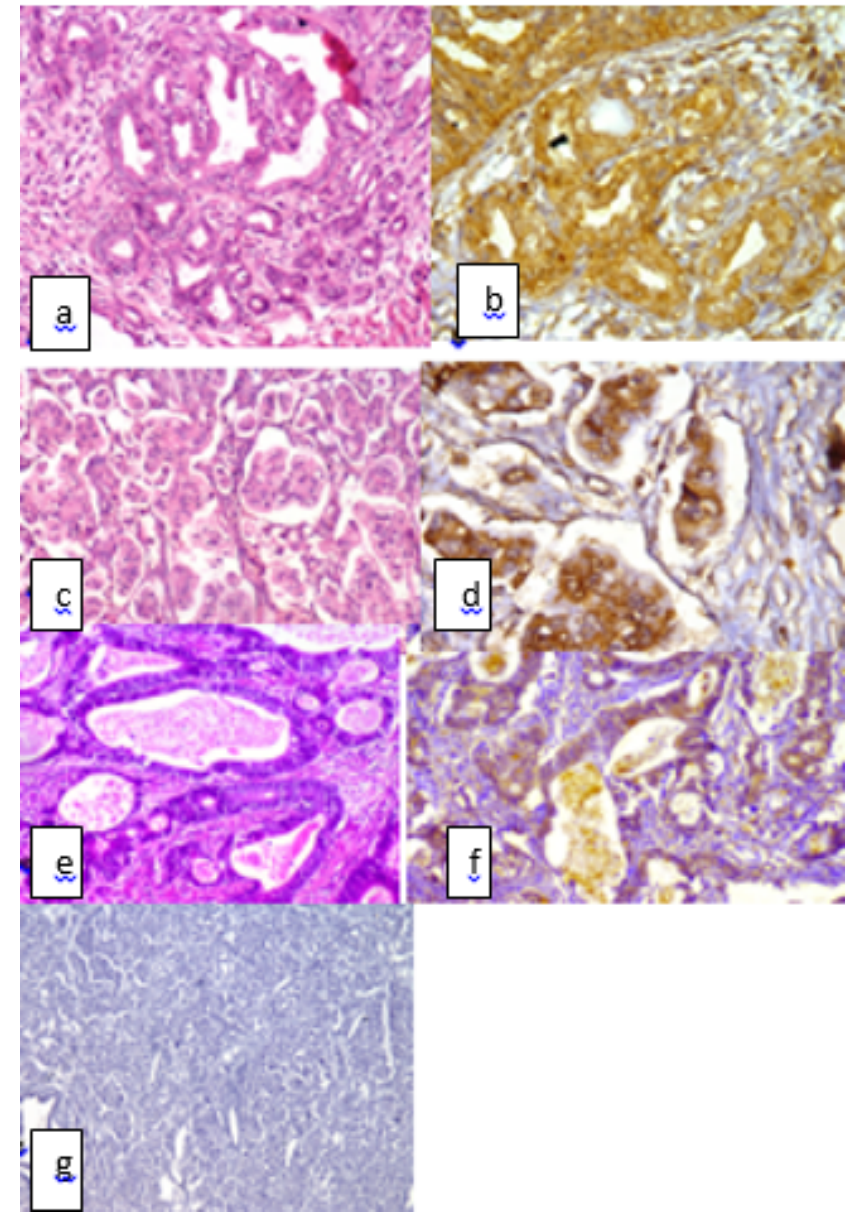

Fig. 1: Expression of DLL-4 in various PDAC\& AA cases: a)Well differentiated PDAC with well-formed acinar structures in desmoplastic stroma (H\&E, X 400). b) DLL4 expression with strong cytoplasmic staining in tumor cells (score 2) \& stromal cells are positive (staining < 10\%) (DLL4, X400).c) Moderately differentiated PDAC with sheets and attempts of acinar structures made by atypical epithelial cells in desmoplastic stroma $\&$ area of micropapillary formation (H\&E, X 400). d) DLL-4 expression with strong cytoplasmic staining in tumor cells (score 2) \& stromal cells are negative (DLL4, X400). e) Moderately differentiated ampullary adenocarcinoma showing sheets \& glandular structures lined by moderately atypical epithelial cells (H\&E, X200). f) DLL4 very weak cytoplasmic expression in epithelial tumor cells in $(<5 \%)$ score $(0)$ with negative expression in stromal cells (DLL4, X200). g) Negative DLL4 expression in normal pancreatic acini (DLL4, x200). 
Table 1: Demographic,clinical and histopathological data of the cases

\begin{tabular}{|c|c|c|c|}
\hline \multirow{3}{*}{ Gender } & & $\operatorname{PDAC}(n=39)(n \& \%)$ & $\operatorname{AA}(n=23)(n \& \%)$ \\
\hline & Male & $30(76.9 \%)$ & $16(69.6 \%)$ \\
\hline & Female & $9(23.1 \%)$ & $7(30.4 \%)$ \\
\hline Age (years) & Mean \pm SD & $58 \pm 9$ & $56.3 \pm 11$ \\
\hline Tumor size & $\begin{array}{l}\leq 2 \mathrm{~cm} \\
>2 \mathrm{~cm}\end{array}$ & $\begin{array}{l}8(20.5 \%) \\
16(41.0 \%) \\
\quad 15(38.5 \%)\end{array}$ & $\begin{array}{l}14(60.9 \%) \\
\quad 9(39.1 \%)\end{array}$ \\
\hline \multirow{3}{*}{ Tumor stage } & $\mathrm{T} 1$ & $8(20.5 \%)$ & $2(8.7 \%)$ \\
\hline & $\mathrm{T} 2$ & $16(41.0 \%)$ & $11(47.8 \%)$ \\
\hline & $\mathrm{T} 3$ & $15(38.5 \%)$ & $10(43.5 \%)$ \\
\hline \multirow{3}{*}{ TNM stage } & Stage1 & $15(38.5 \%)$ & $9(39.1 \%)$ \\
\hline & Stage2 & $21(53.8 \%)$ & $5(21.7 \%)$ \\
\hline & Stage3 & $3(7.7)$ & $9(39.1 \%)$ \\
\hline \multirow{3}{*}{ Histological grades } & Well differentiated & $9(23.1 \%)$ & $9(39.1 \%)$ \\
\hline & Moderately differentiated & $28(71.8 \%)$ & $13(56.5 \%)$ \\
\hline & Poorly differentiated & $2(5.1 \%)$ & $1(4.4 \%)$ \\
\hline \multirow{2}{*}{$\begin{array}{l}\text { Pancreatic neck safety } \\
\text { margin }\end{array}$} & Free & $27(69.2 \%)$ & $19(82.6 \%)$ \\
\hline & infiltrated & $12(30.7 \%)$ & $4(17.3 \%)$ \\
\hline \multirow{2}{*}{ Lympho vascular invasion } & absent & $18(46.2 \%)$ & $15(65.2 \%)$ \\
\hline & present & $21(53.8 \%)$ & $8(34.8 \%)$ \\
\hline \multirow{2}{*}{ Peri-neural invasion } & absent & $4(10.3 \%)$ & $16(69.6 \%)$ \\
\hline & Present & $35(89.7 \%)$ & $7(30.4 \%)$ \\
\hline \multirow{2}{*}{ Lymph Node metastasis } & absent & $20(51.3 \%)$ & $14(60.9 \%)$ \\
\hline & Present & $19(48.6 \%)$ & $9(39.1 \%)$ \\
\hline \multirow{2}{*}{$\begin{array}{l}\text { DLL4 score in stromal } \\
\text { endothelial cells }\end{array}$} & low & $4(10.3 \%)$ & $5(21.7 \%)$ \\
\hline & high & $35(89.7 \%)$ & $18(78.3 \%)$ \\
\hline \multirow{2}{*}{ DLL4 score in tumor cells } & Low & $6(15.4 \%)$ & $8(34.8 \%)$ \\
\hline & High & $33(84.6 \%)$ & $15(65.2 \%)$ \\
\hline OS & Median (Min-max) & $10.00(1-45)$ & $22.00(1-69)$ \\
\hline PFS & Median (Min-max) & $7.00(0-43)$ & $17.50(0-96)$ \\
\hline
\end{tabular}

*P is significant if $<0.05$

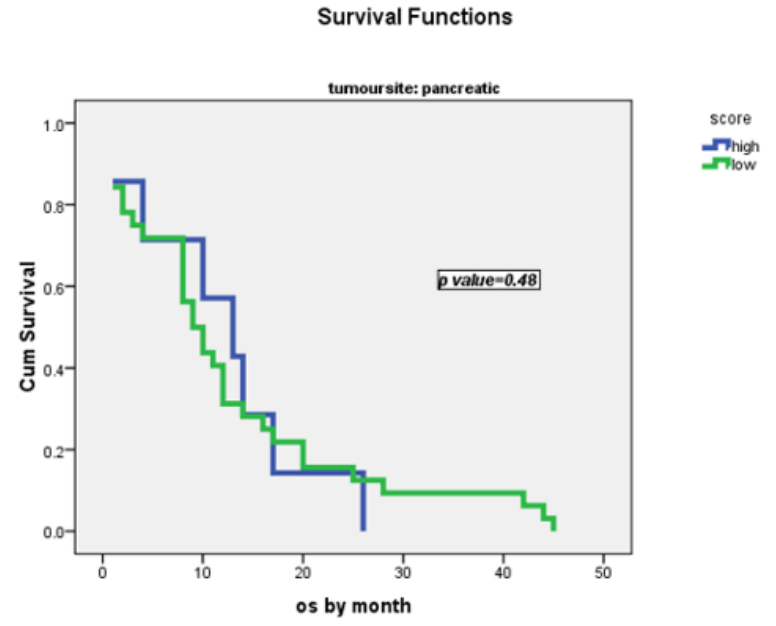

Fig. 2: Overall survival for PDAC cases

(37.1\%). The age of PDAC cases ranged from 40 to 75 years (mean age $58 \pm 9$ years), while the age of AA cases ranged from 30-80 years (mean age $56.3 \pm 11$ years). Similarly,

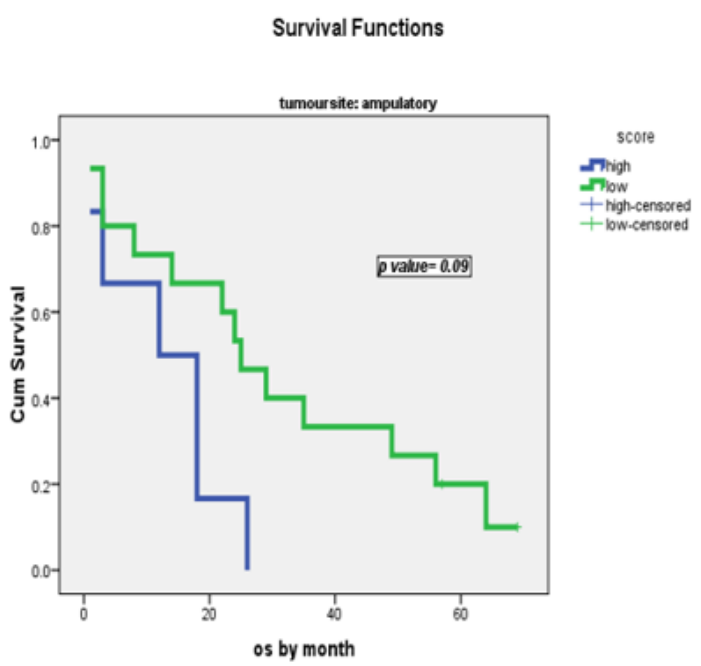

Fig. 3: Overall survival for AA cases 
Table 2: DLL4score expression in tumor cells in relation with different clinico-pathologicalfeatures in PDAC cases and AA cases

\begin{tabular}{|c|c|c|c|c|c|c|c|}
\hline \multirow{2}{*}{$\begin{array}{l}\text { Clinico- } \\
\text { pathological } \\
\text { features }\end{array}$} & & \multicolumn{3}{|c|}{ PDAC } & \multicolumn{3}{|c|}{$\mathbf{A A}$} \\
\hline & & $\begin{array}{c}\text { Low DLL4 } \\
\text { expression } \\
\text { in tumor } \\
\text { cells }(\mathrm{n}=6) \\
(\mathrm{n} \& \%)\end{array}$ & $\begin{array}{l}\text { High DLL4 } \\
\text { expression in tumor } \\
\text { cells }(n=33)(n \& \%)\end{array}$ & $\mathrm{P}$ & $\begin{array}{l}\text { Low DLL4 } \\
\text { score } \\
\text { expression in } \\
\text { tumor cells } \\
(\mathrm{n}=8)(\mathrm{n} \& \%)\end{array}$ & $\begin{array}{l}\text { High DLL4 score } \\
\text { expression in tumor } \\
\text { cells }(\mathrm{n}=15) \\
(\mathrm{n} \& \%)\end{array}$ & $\mathrm{P}$ \\
\hline Gender & $\begin{array}{l}\text { Male } \\
\text { Female }\end{array}$ & $\begin{array}{c}4(66.7 \%) \\
2(33.3 \%)\end{array}$ & $\begin{array}{c}26(78.8 \%) \\
7(21.2 \%)\end{array}$ & 0.42 & $\begin{array}{c}7(87.5 \%) \\
1(12.5 \%)\end{array}$ & $\begin{array}{c}9(60.0 \%) \\
6(40.0 \%)\end{array}$ & 0.19 \\
\hline Age (years) & $\begin{array}{l}\text { Mean } \\
\pm \text { SD }\end{array}$ & $58 \pm 10$ & $57.5 \pm 9$ & 0.91 & $56 \pm 8$ & $57 \pm 13$ & 0.07 \\
\hline Tumor size & $\begin{array}{l}\leq 2 \\
>2\end{array}$ & $\begin{array}{c}1(16.7 \%) \\
(2-4 \mathrm{~cm}) \\
3(50.0 \%) \\
(>4 \mathrm{~cm}) \\
2(33.3 \%)\end{array}$ & $\begin{array}{l}7(21.2 \%) \\
(2-4 \mathrm{~cm}) \\
13(39.4 \%) \\
(>4 \mathrm{~cm}) \\
13(39.4 \%)\end{array}$ & 0.88 & $\begin{array}{l}4(50.0 \%) \\
4(50.0 \%)\end{array}$ & $\begin{array}{r}10(66.7 \%) \\
5(33.3 \%)\end{array}$ & 0.36 \\
\hline Tumor stage & $\begin{array}{l}\text { T1 } \\
\text { T2 } \\
\text { T3 }\end{array}$ & $\begin{array}{l}1(16.7 \%) \\
3(50.0 \%) \\
2(33.3 \%)\end{array}$ & $\begin{array}{l}7(21.2 \%) \\
13(39.4 \%) \\
13(39.4 \%)\end{array}$ & 0.88 & $\begin{array}{c}1(12.5 \%) \\
6(75.0 \%) \\
1(12.5 \%)\end{array}$ & $\begin{array}{l}1(6.7 \%) \\
5(33.3 \%) \\
9(60.0 \%)\end{array}$ & $0.041 *$ \\
\hline $\begin{array}{l}\text { Lymph Node } \\
\text { metastasis }\end{array}$ & $\begin{array}{l}\text { absent } \\
\text { present }\end{array}$ & $\begin{array}{c}4(66.7 \%) \\
2(33.3 \%)\end{array}$ & $\begin{array}{c}16(48.5 \%) \\
17(51.5 \%)\end{array}$ & 0.35 & $\begin{array}{c}5(62.5 \%) \\
3(37.5 \%)\end{array}$ & $\begin{array}{l}9(60.0 \%) \\
6(40.0 \%)\end{array}$ & 0.63 \\
\hline TNM stage & $\begin{array}{l}\text { stage } 1 \\
\text { stage } 2 \\
\text { stage } 3\end{array}$ & $\begin{array}{c}3(50.0 \%) \\
3(50.0 \%) \\
0\end{array}$ & $\begin{array}{c}12(36.4 \%) \\
18(54.5 \%) \\
\quad 3(9.1 \%)\end{array}$ & 0.66 & $\begin{array}{c}5(62.5 \%) 0 \\
0 \% \\
3(37.5 \%)\end{array}$ & $\begin{array}{c}4(26.7 \%) \\
5(33.3 \%) \\
6(40 \%)\end{array}$ & 0.08 \\
\hline $\begin{array}{l}\text { Histological } \\
\text { grade }\end{array}$ & $\begin{array}{l}\text { well } \\
\text { moderate } \\
\text { poor }\end{array}$ & $\begin{array}{c}3(50.0 \%) \\
3(50.0 \%) \\
0\end{array}$ & $\begin{array}{l}6(18.2 \%) \\
25(75.8 \%) \\
2(6.1 \%)\end{array}$ & 0.54 & $\begin{array}{c}4(50.0 \%) \\
4(50.0 \%) \\
0\end{array}$ & $\begin{array}{l}5(33.3 \%) \\
9(60.0 \%) \\
1(6.7 \%)\end{array}$ & 0.6 \\
\hline $\begin{array}{c}\text { Pancreatic } \\
\text { safety margin }\end{array}$ & $\begin{array}{l}\text { Free } \\
\text { infiltrated }\end{array}$ & $\begin{array}{c}4(66.7 \%) \\
2(33.4 \%)\end{array}$ & $\begin{array}{l}23(69.7 \%) \\
10(30.3 \%)\end{array}$ & 0.88 & $\begin{array}{r}6(75.0 \%) \\
2(25 \%)\end{array}$ & $\begin{array}{r}13(86.7 \%) \\
2(13.3 \%)\end{array}$ & 0.48 \\
\hline $\begin{array}{l}\text { Lympho- } \\
\text { vascular } \\
\text { invasion }\end{array}$ & $\begin{array}{l}\text { absent } \\
\text { present }\end{array}$ & $\begin{array}{c}3(50.0 \%) \\
3(50.0 \%)\end{array}$ & $\begin{array}{l}15(45.5 \%) \\
18(54.5 \%)\end{array}$ & 0.59 & $\begin{array}{c}5(62.5 \%) \\
3(37.5 \%)\end{array}$ & $\begin{array}{r}10(66.7 \%) \\
5(33.3 \%)\end{array}$ & 0.59 \\
\hline $\begin{array}{l}\text { Perineural } \\
\text { invasion }\end{array}$ & $\begin{array}{l}\text { absent } \\
\text { present }\end{array}$ & $\begin{array}{c}2(33.3 \%) \\
4(66.7 \%)\end{array}$ & $\begin{array}{c}14(42.4 \%) \\
19(57.6 \%)\end{array}$ & 0.522 & $\begin{array}{c}6(75.0 \%) \\
2(25.0 \%)\end{array}$ & $\begin{array}{c}10(66.7 \%) \\
5(33.3 \%)\end{array}$ & 0.53 \\
\hline $\begin{array}{l}\text { Precursor } \\
\text { lesion }\end{array}$ & $\begin{array}{l}\text { absent } \\
\text { present }\end{array}$ & $\begin{array}{l}0 \\
6(100)\end{array}$ & $\begin{array}{l}0 \\
33(100 \%)\end{array}$ & - & $\begin{array}{c}0 \\
8(100.0 \%)\end{array}$ & $\begin{array}{l}2(13.3 \%) \\
13(86.6 \%)\end{array}$ & 0.27 \\
\hline $\begin{array}{c}\text { Chronic } \\
\text { pancreatitis }\end{array}$ & $\begin{array}{l}\text { absent } \\
\text { present }\end{array}$ & $\begin{array}{c}0 \\
6(100.0 \%)\end{array}$ & $\begin{array}{l}0 \\
33(100.0 \%)\end{array}$ & - & $\begin{array}{c}0 \\
8(100.0 \%)\end{array}$ & $\begin{array}{l}2(13.3 \%) \\
13(86.7 \%)\end{array}$ & 0.41 \\
\hline
\end{tabular}

*P is significant if $<0.05$

Mokhtar et al. (2016) reported an average age of 62 years with an age range of 60-80 years in both PDAC and AA. ${ }^{20}$ Drouillard et al. (2016) (17) and Zhou et al. (2015) showed same mean age of 60 to 62 years. ${ }^{13}$

In the current study, $76.9 \%$ of PDAC cases were males while $23.1 \%$ were females and the male to female ratio was 3.3:1. In AA, males were $69.9 \%$ and females were $30.4 \%$ of all cases with a lower male to female ratio (2.3:1). In contrast, the national cancer institute (NCI) in Egypt (2016) found a lower percentage for male PDAC cases (53\%) and a higher percentage for female cases (47\%). In addition, gender distribution for all peri-ampullary malignant cases was $60.84 \%$ and $39.16 \%$ for males and females, respectively (20). Drouillard et al. (2016) reported a slightly lower percentage of male cases $(65 \%)$ and female cases $(35 \%)$ in PDAC. ${ }^{18}$ This divergence in ratios in different studies could be due to racial causes or difference in exposure to risk factors.

Regarding tumor size, the majority for PDAC cases $(69.2 \%)$ in our study was $>2 \mathrm{~cm}$. Zhou, et al. (2015) reported that tumors $>2.5 \mathrm{~cm}$ were $(66.7 \%)$ in keeping with the present results. ${ }^{13}$ However, the majority of AA cases in our study were tumors $\leq 2 \mathrm{~cm}(60.9 \%)$ in agreement with Marwa Ferchichi et al. (2019) who found that AA had a mean size of $2.2 \mathrm{~cm} .^{21}$

Regarding tumor stage in our study, majority of PDAC cases were T2 (41\%). However, Drouillard et al. (2016) reported a higher percentage of T3 which was $(86.7 \%) .{ }^{17}$ This can be explained by cases selection and number of cases. Regarding AA, the majority of our cases were T2 $(47.8 \%)$ that were related to tumor microscopic extension in agreement with Marwa Ferchichi et al. (2019). ${ }^{21}$

Our study showed that in PDAC, positive lymph node metastasis was detected in $48.6 \%$ of cases while Drouillard 
Table 3: DLL4 score expression in stromal cells inrelation with different clinico-pathological features in PDAC cases and AAcases

\begin{tabular}{|c|c|c|c|c|c|c|c|}
\hline \multirow{2}{*}{$\begin{array}{l}\text { Clinico- } \\
\text { pathological } \\
\text { features }\end{array}$} & & \multicolumn{3}{|c|}{ PDAC } & \multicolumn{3}{|c|}{$\mathbf{A A}$} \\
\hline & & $\begin{array}{l}\text { Negative DLL4 } \\
\text { stromal cell } \\
\text { expression } \\
\mathrm{N}=4(\mathrm{n} \& \%)\end{array}$ & $\begin{array}{l}\text { Positive DLL4 } \\
\text { stromal cell } \\
\text { expression } \\
\mathrm{N}=35 \text { (n \&\%) }\end{array}$ & $\mathrm{P}$ & $\begin{array}{l}\text { Negative DLL4 } \\
\text { stromal cell } \\
\text { expression } \mathrm{N}=5 \text { (n } \\
\& \%)\end{array}$ & $\begin{array}{l}\text { positive DLL4 } \\
\text { stromal cell } \\
\text { expression } \mathrm{N}=18 \\
(\mathrm{n} \& \%)\end{array}$ & $\mathrm{P}$ \\
\hline Gender & $\begin{array}{l}\text { Male } \\
\text { Female }\end{array}$ & $\begin{array}{l}2(50.0 \%) \\
2(50.0 \%)\end{array}$ & $\begin{array}{c}28(80.0 \%) \\
7(20.0 \%)\end{array}$ & 0.22 & $\begin{array}{c}5(100.0 \%) \\
0\end{array}$ & $\begin{array}{c}11(61.1 \%) \\
7(38.9 \%)\end{array}$ & 0.13 \\
\hline Age & $\begin{array}{l}\text { Mean } \\
\pm \mathrm{SD}\end{array}$ & $63.8 \pm 11$ & $57 \pm 9$ & 0.53 & $56.5 \pm 7$ & $56.3 \pm 12$ & 0.857 \\
\hline Tumor size & $\begin{array}{l}\leq 2 \\
>2\end{array}$ & $\begin{array}{c}0 \\
(2-4 \mathrm{~cm}) \\
3(75.0 \%) \\
(>4 \mathrm{~cm}) \\
1(25.0 \%)\end{array}$ & $\begin{array}{l}8(22.9 \%) \\
(2-4 \mathrm{~cm}) 13 \\
(37.1 \%) \\
(>4 \mathrm{~cm}) \\
14(40.0 \%)\end{array}$ & 0.83 & $\begin{array}{c}4(80 \%) \\
1(20 \%)\end{array}$ & $\begin{array}{c}10(55.6 \%) \\
8(44.4 \%)\end{array}$ & 0.32 \\
\hline Tumor stage & $\begin{array}{c}\mathrm{T} 1 \\
\mathrm{~T} 2 \\
\mathrm{~T} 3\end{array}$ & $\begin{array}{c}0 \\
3(75.0 \%) \\
1(25.0 \%)\end{array}$ & $\begin{array}{l}8(22.9 \%) \\
13(37.1 \%) \\
14(40.0 \%)\end{array}$ & 0.83 & $\begin{array}{l}1(20.0 \%) \\
2(40.0 \%) \\
2(40.0 \%)\end{array}$ & $\begin{array}{c}1(5.6 \%) \\
9(50.0 \%) \\
8(44.4 \%)\end{array}$ & 0.59 \\
\hline $\begin{array}{l}\text { Lymph Node } \\
\text { metastasis }\end{array}$ & $\begin{array}{l}\text { absent } \\
\text { present }\end{array}$ & $\begin{array}{l}2(50.0 \%) \\
2(50.0 \%)\end{array}$ & $\begin{array}{c}18(51.4 \%) \\
17(48.6 \%)\end{array}$ & 0.67 & $\begin{array}{l}4(80.0 \%) \\
1(20.0 \%)\end{array}$ & $\begin{array}{c}10(55.6 \%) \\
8(44.4 \%)\end{array}$ & 0.32 \\
\hline TNM stage & $\begin{array}{l}\text { stage } 1 \\
\text { stage } 2 \\
\text { stage } 3\end{array}$ & $\begin{array}{l}2(50.0 \%) \\
1(25.0 \%) \\
1(25.0 \%)\end{array}$ & $\begin{array}{r}13(37.1 \%) \\
20(57.1 \%) \\
2(5.7 \%)\end{array}$ & 0.27 & $\begin{array}{l}2(40.0 \%) \\
2(40.0 \%) \\
1(20.0 \%)\end{array}$ & $\begin{array}{l}7(38.9 \%) \\
3(16.6 \%) \\
8(44.4 \%)\end{array}$ & 0.64 \\
\hline $\begin{array}{l}\text { Histological } \\
\text { grade }\end{array}$ & $\begin{array}{l}\text { well } \\
\text { moderate }\end{array}$ & $\begin{array}{c}2(50.0 \%) \\
2(50.0 \%) \\
0\end{array}$ & $\begin{array}{c}7(20.0 \%) \\
26(74.3 \%) \\
2(5.7 \%)\end{array}$ & 0.38 & $\begin{array}{c}2(40.0 \%) \\
3(60.0 \%) \\
0\end{array}$ & $\begin{array}{c}7(38.9 \%) \\
10(55.6 \%) \\
1(5.6 \%)\end{array}$ & 0.86 \\
\hline $\begin{array}{c}\text { Pancreatic } \\
\text { safety margin }\end{array}$ & $\begin{array}{l}\text { poor } \\
\text { Free } \\
\text { infiltrated }\end{array}$ & $\begin{array}{l}3(75.0 \%) \\
1(25.0 \%)\end{array}$ & $\begin{array}{c}24(68.6 \%) \\
11(31.4 \%)\end{array}$ & 0.79 & $\begin{array}{l}4(80.0 \%) \\
1(20.0 \%)\end{array}$ & $\begin{array}{c}15(83.3 \%) \\
3(16.7 \%)\end{array}$ & 0.77 \\
\hline $\begin{array}{l}\text { Lympho- } \\
\text { vascular } \\
\text { invasion }\end{array}$ & $\begin{array}{l}\text { absent } \\
\text { present }\end{array}$ & $\begin{array}{l}2(50.0 \%) \\
2(50.0 \%)\end{array}$ & $\begin{array}{c}16(45.7 \%) \\
19(54.3 \%)\end{array}$ & 0.63 & $\begin{array}{c}5(100.0 \%) \\
0\end{array}$ & $\begin{array}{r}10(55.6 \%) \\
8(44.4 \%)\end{array}$ & 0.86 \\
\hline $\begin{array}{l}\text { Perineural } \\
\text { invasion }\end{array}$ & $\begin{array}{l}\text { absent } \\
\text { present }\end{array}$ & $\begin{array}{l}2(50.0 \%) \\
2(50.0 \%)\end{array}$ & $\begin{array}{c}14(40.0 \%) \\
21(60.0 \%)\end{array}$ & 0.54 & $\begin{array}{c}5(100.0 \%) \\
0\end{array}$ & $\begin{array}{r}11(61.1 \%) \\
7(38.9 \%)\end{array}$ & 0.09 \\
\hline Precursor lesion & $\begin{array}{l}\text { absent } \\
\text { present }\end{array}$ & $\begin{array}{c}1(25.0 \%) \\
3(75 \%)\end{array}$ & $\begin{array}{c}1(2.9 \%) \\
34(96.1)\end{array}$ & 0.05 & $\begin{array}{l}0 \\
5(100.0 \%)\end{array}$ & $\begin{array}{l}1(5.6 \%) \\
17(94.4 \%)\end{array}$ & 0.78 \\
\hline $\begin{array}{c}\text { Chronic } \\
\text { pancreatitis }\end{array}$ & $\begin{array}{l}\text { absent } \\
\text { present }\end{array}$ & $\begin{array}{c}0 \\
4(100.0 \%)\end{array}$ & $\begin{array}{c}0 \\
35(100.0 \%)\end{array}$ & - & $\begin{array}{l}0 \\
5(100.0 \%)\end{array}$ & $\begin{array}{l}2(11.1 \%) \\
16(88.9 \%)\end{array}$ & 0.6 \\
\hline
\end{tabular}

*P is significant if $<0.05$

et al. (2016) reported a higher percentage $(69 \%)$ of positive lymph node metastasis. ${ }^{18}$ Lymph node metastasis was $(39 \%)$ in AA cases.

TNM staging of our PDAC cases showed predominance of stage I/II representing $92.3 \%$ collectively. Drouillard et al. (2016) reported a lower percentage $(62 \%)$ for stage I/II cases. ${ }^{18}$ In AA, stage I/II accounted for $65.1 \%$ of cases.

Histological grading of our PDAC cases was mainly well/moderately differentiated in $95 \%$ of cases and was only poorly differentiated in $5 \%$ of cases. However, Drouillard et al. (2016) reported a well/moderately differentiated in $78 \%$ of cases and poorly differentiated in $22 \%$ of cases. ${ }^{18}$ Also, the studied cases of Zhou et al. (2015) were of lower percentage, $74 \%$ were well/moderate differentiated. In AA, $95.6 \%$ of cases were well differentiated and moderately differentiated while $4.4 \%$ of cases were poorly differentiated. ${ }^{13}$
Regarding pancreatic safety margin, $69.2 \%$ of our PDAC cases had negative margins. However, Drouillard et al. (2016) found a higher percentage of negative margins $(89 \%)$. This can be explained by cases selection as we excluded T4 and M1 cases. ${ }^{18}$ In AA cases, $82.6 \%$ had negative margins.

Lymphovascular emboli were detected in $53.8 \%$ of our PDAC cases. In agreement with that, Drouillard et al. (2016) reported a similar percentage $(53 \%)$ of positive cases. ${ }^{18}$ In AA cases, $(34.8 \%)$ cases were positive.

Perineural invasion was positive in $90 \%$ of our PDAC cases. Drouillard et al. (2016) reported nearly similar percentage $(80 \%)$ of positive cases. ${ }^{18}$ In AA, only $30.4 \%$ of cases were positive.

In the present study, we observed a high expression of DLL4 in tumor cells in $84.6 \%$ of PDAC cases. However, Drouillard et al. (2016) and Zhou et al. (2015) reported a 
Table 4: Univariateanalysis regarding overall survival (OS) in pancreatic and ampullary cases

\begin{tabular}{|c|c|c|c|c|c|c|c|c|}
\hline \multirow[b]{3}{*}{ Sex } & \multicolumn{4}{|c|}{ OS univariate analysis (PDAC) } & \multicolumn{4}{|c|}{ OS univariate analysis (AA) } \\
\hline & \multicolumn{3}{|c|}{ HR $(95 \% \mathrm{CI})$} & \multirow{2}{*}{$\begin{array}{c}\mathrm{P} \text { value } \\
0.83\end{array}$} & \multicolumn{3}{|c|}{ HR $(95 \% \mathrm{CI})$} & \multirow{2}{*}{$\begin{array}{c}\mathrm{P} \text { value } \\
0.2\end{array}$} \\
\hline & 1.090 & $(.509$ & 2.335) & & .509 & $(.178$ & $1.459)$ & \\
\hline Age & 1.253 & .816 & 1.926 & 0.64 & 2.357 & .945 & 5.879 & $0.02 *$ \\
\hline Tumor size & 1.253 & .816 & 1.926 & 0.3 & 1.389 & .566 & 3.406 & 0.47 \\
\hline Histological grade & 1.081 & .498 & 2.349 & 0.84 & .960 & .375 & 2.457 & 0.9 \\
\hline Pancreatic safety margin & .945 & 633 & 1.412 & 0.78 & 1.192 & .500 & 2.844 & 0.7 \\
\hline Lymphovascular invasion & 1.070 & .564 & 2.030 & 0.83 & .485 & .170 & 1.382 & 0.15 \\
\hline Perineural invasion & 1.285 & .668 & 2.472 & 0.45 & 1.073 & .400 & 2.879 & 0.88 \\
\hline $\mathrm{T}$ (Tumor stage) & 1.329 & .862 & 2.049 & 0.19 & 1.056 & .585 & 1.905 & 0.85 \\
\hline $\mathrm{N}$ (Nodal stage) & 1.185 & .634 & 2.216 & 0.59 & .540 & .201 & 1.451 & 0.2 \\
\hline TNM stage & 1.121 & .663 & 1.896 & 0.76 & .766 & .460 & 1.276 & 0.3 \\
\hline Score tumor cell & 1.224 & .570 & 2.627 & 0.59 & .427 & .159 & 1.148 & 0.09 \\
\hline Score stromal endothelial cell & .786 & .276 & 2.239 & 0.64 & 1.159 & .406 & 3.306 & 0.87 \\
\hline Sex & 1.090 & $(.509$ & 2.335) & 0.83 & .509 & $(.178$ & $1.459)$ & 0.2 \\
\hline
\end{tabular}

*P is significant if $<0.05$

Table 5: Univariateanalysis regarding progression free survival (PFS) in pancreatic \&ampullary cases

\begin{tabular}{|c|c|c|c|c|c|c|c|c|}
\hline \multirow[b]{3}{*}{ Sex } & \multicolumn{4}{|c|}{ PFS univariate analysis (pancreatic) } & \multicolumn{4}{|c|}{ PFS univariate analysis (ampullary) } \\
\hline & \multicolumn{3}{|c|}{$\mathrm{HR}(95 \% \mathrm{CI})$} & \multirow{2}{*}{$\begin{array}{c}\text { P value } \\
.736\end{array}$} & \multicolumn{3}{|c|}{$\mathrm{HR}(95 \% \mathrm{CI})$} & \multirow{2}{*}{$\begin{array}{c}\mathrm{P} \\
\text { value } \\
.161\end{array}$} \\
\hline & 1.143 & .529 & 2.469 & & 494 & .176 & 1.390 & \\
\hline Age & 1.012 & .979 & 1.046 & .485 & 966 & .920 & 1.013 & .157 \\
\hline $\mathrm{T}$ size & 1.278 & .836 & 1.954 & 00.25 & 1.211 & .511 & 2.874 & 0.66 \\
\hline Histological grades & 1.131 & .526 & 2.435 & 0.75 & 1.194 & .483 & 2.947 & 0.68 \\
\hline Pancreatic safety margin & .944 & .634 & 1.405 & .774 & 1.095 & .458 & 2.616 & .841 \\
\hline Lymphovascular invasion & 1.138 & .605 & 2.143 & 688 & .488 & .175 & 1.362 & .150 \\
\hline Perineural invasion & 1.472 & .766 & 2.831 & 0.24 & .918 & .349 & 2.415 & 0.86 \\
\hline $\mathrm{T}$ (Tumor stage) & 1.341 & .877 & 2.049 & 0.17 & 1.051 & .588 & 1.878 & 0.86 \\
\hline $\mathrm{N}$ (Nodal stage) & 1.310 & .709 & 2.420 & 0.39 & .540 & .205 & 1.423 & 0.19 \\
\hline TNM stage & 1.179 & .707 & 1.967 & 0.53 & .740 & .448 & 1.224 & 0.23 \\
\hline Score tumor cell & 1.272 & .593 & 2.727 & 0.52 & .477 & .183 & 1.242 & 0.19 \\
\hline Score stromal endothelial cell & .802 & .281 & 2.286 & 0.76 & 1.071 & .381 & 3.015 & 0.89 \\
\hline
\end{tabular}

$* \mathrm{P}$ is significant if $<0.05$

lower percentage for high DLL4 expression in tumor cells in $60.2 \%$ and $64.3 \%$ of PDAC patients, respectively. ${ }^{13,18}$ Also, we observed a high expression of DLL4 in tumor cells in $65.2 \%$ of AA cases. Ishigami et al. (2013) reported tumor cell DLL4 expression in $49 \%$ of gastric cancer patients. ${ }^{12}$

In the current study, stromal expression of DLL4 was present in $89.7 \%$ of PDAC cases and in $78.3 \%$ of AA cases. Zhou et al. (2015) study analyzed DLL4 protein expression both in tumor and stromal endothelial cells, and high expressions were observed in 64.3 and $52.4 \%$ of PDAC cases. ${ }^{13}$ However, Ishigami et al. (2013) reported stromal expression of DLL4 in $23 \%$ gastric carcinoma cases (22). Moreover, stromal DLL4 expression in breast carcinoma cases was $79 \% .^{22}$
Our work showed that there was no statistically significant relation between age or gender of patients and DLL4 expression in both tumor and stromal cells. In agreement with that, Drouillard et al. (2016) and Zhou et al. (2015) reported the same results. ${ }^{13,18}$

The current work showed that high DLL4 tumor cell expression was associated with increased tumor size in PDAC but without significant relation and that agrees with Drouillard et al. (2016). ${ }^{18}$ However, Zhou et al. (2015) reported a statistically significant relation with $50 \%$ of studied PDAC cases showing a high expression in tumor cells and size $>2.5 \mathrm{~cm}$. There was no significant relation between DLL4 expression in stromal cells and tumor size in PDAC and this also was reported by Zhou et al. (2015). ${ }^{13}$ 


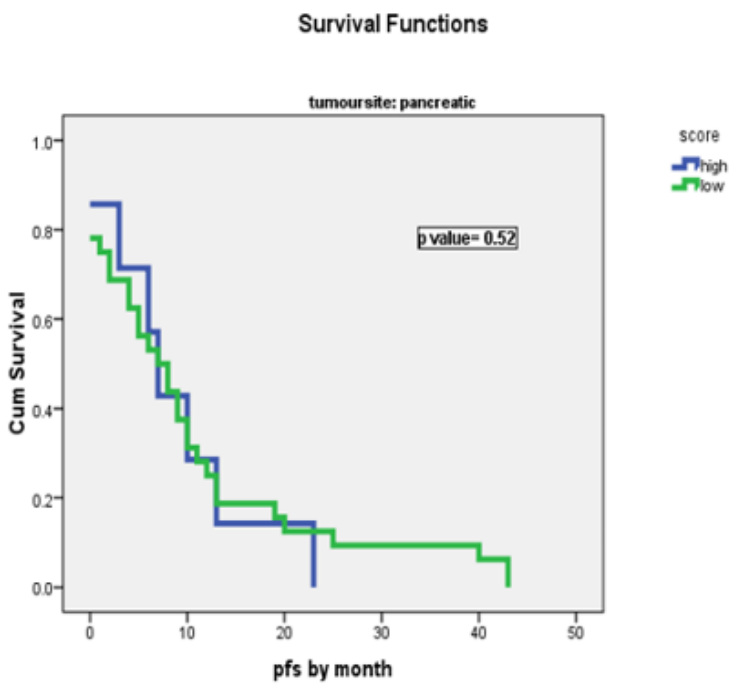

Fig. 4: Progression free survival for PDAC cases

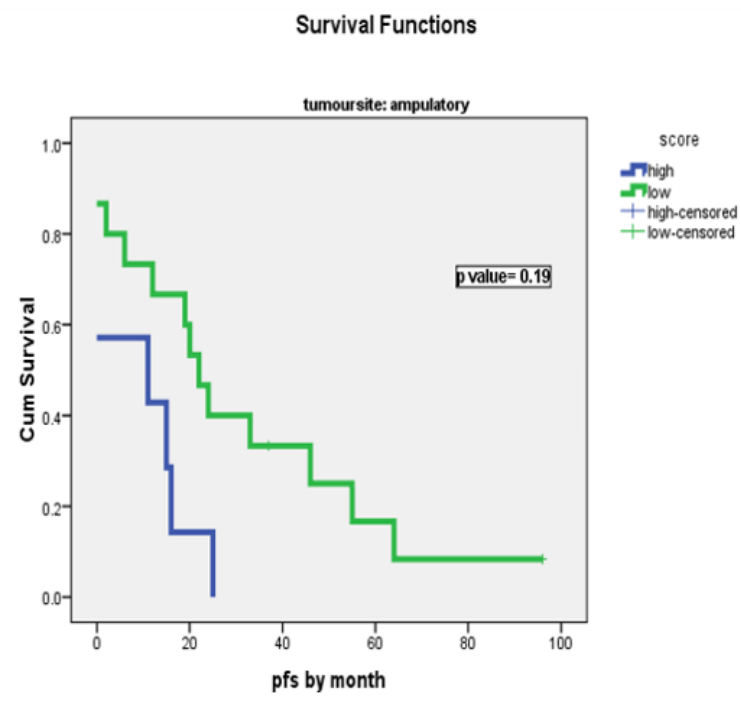

Fig. 5: Progression free survival for AA cases

In the current study, in PDAC, we observed nonsignificant relationship between DLL4 expression in tumor cells and stromal cells regarding clinicopathological parameters. However, Drouillard et al. (2016) observed that high DLL4 tumor cells expression was significantly related with histological grade. ${ }^{18}$ Also, Zhou et al. (2015) observed that high expression of DLL4 in both tumor and stromal cells was significantly correlated with histological grade, tumor stage, node stage and TNM stage of PDAC. ${ }^{13}$

In our AA cases, there was a significant relation between DLL4 tumor cell expression and tumor stage. There was no significant relationship regarding pancreatic safety margin, lymph node metastasis and TNM stage.
In our study, survival analysis revealed that patients with high DLL4 expression had poorer overall survival when compared with low DLL4 expression patients, although it did not reach a statistical significance either in PDAC or AA patients $(\mathrm{P}=0.48$ and 0.09$)$, respectively. However, Drouillard et al. reported a high statistically significant association between DLL4 expression and both overall and disease free survivals $\left(\mathrm{P}=0.004\right.$ and $\mathrm{P}=0.02$, respectively). ${ }^{18}$

These results are similar to that observed by Zhou et al. who reported that over expression of DLL4 and CD105 in pancreatic tumors was associated with shorter overall survival. ${ }^{13}$ However, by multivariate analysis, DLL4 and CD105 were not found to be an independent prognostic marker, which may be influenced by the strong association with lymph node metastasis.

Since frequent tumor relapse after treatment is a major obstacle in pancreatic cancer patients, progression free survival was important to be evaluated also, and patients with low DLL4 expression in our study showed a nonsignificant longer progression free survival $(\mathrm{P}=0.52)$. Also, In AA cases, DLL4 was not statistically significant regarding the patient progression free survival $(\mathrm{P}=0.19)$ although it influenced it by some way.

In this work, overexpression of DLL4 in AA had a shorter overall and progression free survival in comparison to PDAC but without significance and to the best of our knowledge, there is no comparative study was done in this issue. However, Santini et al. (2005) examined the possible prognostic significance of an angiogenesis marker as VEGF in a homogeneous cohort of patients with radically resected cancer of the ampulla of Vater and reported the absence of a prognostic role of angiogenesis in this type of cancer. ${ }^{8}$

Larger number of samples and longer periods of follow up are needed to obtain better results. Also, we only included resectable patients, so later stage (IV) was absent in our study and this may explain the different results of this study to other studies that included resectable and non resectable patients.

Up till now, there is no effective adjuvant therapy in preventing recurrence in both pancreatic and ampullary tumors. Our results indicated that an examination of high DLL4 expression in resected tumors can give us additional information in identifying patients who have a high risk for disease recurrence and thus need intense and different postoperative adjuvant therapy.

\section{Conclusion}

Based on the current study findings, it can be concluded that DLL4 can't be used as a diagnostic marker. Likewise, it can't be used to differentiate between pancreatic ductal and ampullary adenocarcinomas. However, DLL4 expression can be used as a poor prognostic factor for both PDAC and AA. Further studies should be done on larger number of PDAC and AA cases. 


\section{Source of Funding}

None.

\section{Conflict of Interest}

None.

\section{References}

1. Gordon-Dseagu VL, Devesa SS, Goggins M, Stolzenberg-Solomon R. Pancreatic cancer incidence trends: evidence from the Surveillance, Epidemiology and End Results (SEER) population-based data. Int $J$ Epidemiol. 2018;47(2):427-39.

2. Jemal A, Miller KD, Ma J. Higher Lung Cancer Incidence in Young Women Than Young Men in the United States. $N$ Engl J Med. 2018;378(21):1999-2009.

3. Bledsoe JR, Shinagare SA, Deshpande V. Difficult Diagnostic Problems in Pancreatobiliary Neoplasia. Arch Pathol Lab Med. 2015;139(7):848-57

4. Albores-Saavedra J, Hruban R, Klimstra D, Zamboni G. Invasive adenocarcinoma of the ampullary region. WHO classification of tumours of the digestive system Lyon. Int Agency Res Cancer (IARC). 2010;p. 87-91.

5. Abraham UM, Ramkumar S. Correlation between Immunohistochemical and Histomorphological Features of Ampullary Carcinomas: A Study on 72 Cases from a Tertiary Health Care Center. Gastroenterol Res Pract. 2020;2020:1-9.

6. Chen HT, Cai QC, Zheng JM. High Expression of Delta-Like Ligand 4 Predicts Poor Prognosis After Curative Resection for Pancreatic Cancer. Ann Surg Oncol. 2012;19(3):464-74.

7. Ferrara N. VEGF-A: a critical regulator of blood vessel growth. Eur Cytokine Netw. 2009;20(4):158-63.

8. Santini D, Vincenzi B, Perrone G, Rabitti C, Borzomati D, Valeri S, et al. Vascular endothelial growth factor (VEGF) expression is not associated with prognosis in patients with radically resected ampullary carcinoma. Ann Oncol. 2005;16(11):1847-8.

9. Lobov IB, Renard RA, Papadopoulos N, Gale NW, Thurston G, Yancopoulos GD, et al. Delta-like ligand 4 (Dll4) is induced by VEGF as a negative regulator of angiogenic sprouting. Proce National Acad Sci. 2007;104(9):3219-24.

10. Donnem T, Andersen S, Al-Shibli K, Al-Saad S, Busund LT, Bremnes $\mathrm{RM}$, et al. Prognostic impact of Notch ligands and receptors in nonsmall cell lung cancer. Cancer. 2010;116(24):5676-85.

11. Wang W, Yu Y, Wang Y. Delta-like ligand 4: A predictor of poor prognosis in clear cell renal cell carcinoma. Oncol lett. 2014;8(6):2627-33.

12. Ishigami $\mathrm{S}$, Arigami $\mathrm{T}$, Uenosono $\mathrm{Y}$, Okumura $\mathrm{H}$, Kurahara $\mathrm{H}$, Uchikado Y, et al. Clinical implications of DLL4 expression in gastric cancer. J Exp Clin Cancer Res. 2013;32(1):46.

13. Zhou L, Yu L, Ding G. Overexpressions of DLL4 and CD105 are associated with poor prognosis of patients with pancreatic ductal adenocarcinoma. Pathol Oncol Res. 2015;21(4):1141-7.

14. Oishi H, Sunamura M, Egawa S, Motoi F, Unno M, Furukawa T, et al Blockade of Delta-Like Ligand 4 Signaling Inhibits Both Growth and Angiogenesis of Pancreatic Cancer. Pancreas. 2010;39(6):897-903.
15. Yen WC, Fischer MM, Hynes M, Wu J, Kim E, Beviglia L, et al. AntiDLL4 Has Broad Spectrum Activity in Pancreatic Cancer Dependent on Targeting DLL4-Notch Signaling in Both Tumor and Vasculature Cells. Clin Cancer Res. 2012;18(19):5374-86.

16. Kwon J, Kim K, Chie EK, Kim BH, Jang JY, Kim SW, et al. Prognostic relevance of lymph node status for patients with ampullary adenocarcinoma after radical resection followed by adjuvant treatment. Eur J Surg Oncol. 2017;43(9):1690-6.

17. Ramos-Vara JA. Principles and methods of immunohistochemistry. Drug Saf Eval. 2011;p. 83-96.

18. Drouillard A, Puleo F, Bachet JB, Ouazzani S, Calomme A, Demetter $\mathrm{P}$, et al. DLL4 expression is a prognostic marker and may predict gemcitabine benefit in resected pancreatic cancer. $\mathrm{Br} \mathrm{J}$ Cancer. 2016;115(10):1245-52.

19. Martinez JC, Müller MM, Turley H. Nuclear and membrane expression of the angiogenesis regulator delta-like ligand 4 (DLL4) in normal and malignant human tissues. Histopathol. 2009;54(5):598606.

20. Mokhtar N, Salama A, Badawy O, Khorshed E, Mohamed G, Ibrahim M, et al. Cancer pathology registry 2000-2011. vol. 2. Cairo, Egypt: National Cancer Institute Cairo University; 2000. p. 8-31.

21. Ferchichi M, Jouini R, Koubaa W, Khanchel F, Helal I, Hadad D, et al. Ampullary and pancreatic adenocarcinoma-a comparative study. $J$ Gastrointest Oncol. 2019;10(2):270-5.

22. Jubb AM, Miller KD, Rugo HS, Harris AL, Chen D, Reimann JD, et al. Impact of Exploratory Biomarkers on the Treatment Effect of Bevacizumab in Metastatic Breast Cancer. Clin Cancer Res. 2011;17(2):372-81.

\section{Author biography}

Ikbal A Elkholy Assistant Lecturer

Asmaa M I Gado Professor

Mie A Mohammad Professor

Dalia H M Zayed Assistant professor

Hend M H R Elkalla Assistant professor

Ahmed M A Elhilali Lecturer

Sherine Refat Lecturer

Cite this article: Elkholy IA, Gado AMI, Mohammad MA, Zayed DHM, Elkalla HMHR, Elhilali AMA, Refat S. Pattern of expression of Delta-like ligand 4 (DLL-4) in patients with pancreatic ductal and ampullary adenocarcinomas and its clinicopathological prognostic implications. IP J Diagn Pathol Oncol 2020;5(3):257-266. 